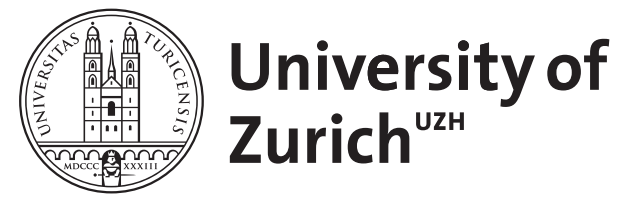
Archive

University of Zurich

University Library

Strickhofstrasse 39

CH-8057 Zurich

www.zora.uzh.ch

Year: 2012

\title{
Moral development in early childhood is key for moral enhancement
}

Christen, Markus ; Narvaez, Darcia

DOI: https://doi.org/10.1080/21507740.2012.721460

Posted at the Zurich Open Repository and Archive, University of Zurich

ZORA URL: https://doi.org/10.5167/uzh-71408

Journal Article

Accepted Version

Originally published at:

Christen, Markus; Narvaez, Darcia (2012). Moral development in early childhood is key for moral enhancement. AJOB Neuroscience, 3(4):25-26.

DOI: https://doi.org/10.1080/21507740.2012.721460 


\section{Moral Development in Early Childhood Is Key for Moral Enhancement}

Markus Christen, University of Zürich and University of Notre Dame

Darcia Narvaez, University of Notre Dame

Moral enhancement, outlined in the well-elaborated typology by John Shook (2012), is the most recent strain in the enhancement debate that unfolded in the last decade-but the ideal of "becoming a morally better person" is probably among the oldest topics in practical philosophy and pedagogy. However, the topic of "moral enhancement" offers the new idea that knowledge of the biological foundation of human moral behavior may allow for interventions into the "neuronal infrastructure" of morality in order to improve the behavior of people or, at least, to diminish some forms of evil that result, for example, from prefrontal lesions (Sobhani and Bechara 2011). With moral enhancements, one might avoid the long and troublesome shaping of morality through education and/or correction, although enhancement would raise many philosophical and practical problems, as outlined by John Shook and others. In our contribution, we raise three points: the importance of moral development in early life and its implications, the nature of virtue, and existing methods of educational enhancement and non-invasive enhancements.

These points are important, as in Shook's contribution (and in many others that discuss moral enhancement) an understanding of the importance of early experience is missing. Humans are born with only $25 \%$ of the brain developed (reaching about $90 \%$ complete by age 5 years; Trevathan 2011). Much of early experience involves the co-construction of brain circuitries through interactions with caregivers that have a direct bearing on moral functioning later. Examples are subcortical emotion systems of "play" and "care" (Panksepp 1998) and cortical areas of the prefrontal cortex, such as the orbitofrontal cortex and the anterior cingulate cortex (Schore 2013). Initial conditions of human development and the epigenetic and developmental plasticity of brain/body have long-term consequences for well-being and morality (Narvaez 2008). The early caregiving environment influences the development of many basic systems such as stress reactivity, impacting physical and mental health outcomes later in life (Lupien et al. 2008). For example, children with inconsistent or non-responsive caregivers can develop emotional dysregulation which becomes the foundation for further psychopathology such as depression, aggression, compromised social abilities and lifelong anxiety (Schore 2013).

Given this unfolding knowledge on the connection between brain development and moral development, it is obvious that there are links to moral enhancement-understood as the endeavor to improve the moral behavior in a neuroscientifically informed way. We mention two implications here. First, particular parenting practices foster optimal brain development that underlies the moral behavior of adults - so these practices might be promulgated widely and supported by institutional structures (Narvaez et al. 2013). For example, caregiving practices for young children with known effects on moral functioning (with sample findings) include breastfeeding (empathy), prompt response to needs (conscience), touch (inhibitory control), keeping mom and child together after birth (selfregulation), play (low aggression), and maternal support (low stress reactivity). Second, one might use knowledge about the conditions of how an adult grew up to make recommendations for interventions to improve basic moral competences (Tanner and Christen in press). Stress reactivity can play a large role in the type of moral mindset a person adopts, altering perception and perceived 
affordances (Narvaez 2008), but with sufficient effort, brains can be self-altered for change of focus and improved functioning (e.g., Doidge 2007).

Another point that should be made is about virtue. What is it? According to the esteemed Aristotle, it is acting skillfully in the right way at the right time with the right feelings. Virtue does not follow laws or rules beyond a contextualized golden mean. This means that moral enhancement cannot be given in measured dosages with predictable outcomes. Instead, a capacity-building approach that ensures that each person has the tools required for virtuous behavior may be better (Narvaez 2006). Such tool building occurs in moral and character education programs around the world (cf. Nucci and Narvaez 2008). Indeed, the five factors identified by Shook for moral enhancement overlap with educational interventions in primary, secondary, postsecondary, and professional schools. Interventions often focus on one or more of four components that comprise moral behavior (identified by James Rest and extended by Narvaez [2006]): ethical sensitivity (perception and interpretation), ethical reasoning and judgment, ethical motivation and identity, implementation and follow-through. Each component comprises a set of skills and capacities for action that can be cultivated toward expertise. Having a set of ethical capacities honed to automaticity, as in expertise, makes it more likely that an individual will act virtuously.

Given the connection between moral development and moral enhancement, neuroscientifically informed interventions during childhood may actually be a preferable approach to moral enhancement, especially in comparison to the types of interventions Shook described (e.g., pharmacologically based interventions). Early and educational interventions can be culturally sensitive and tailored to the needs of the individual. Interventions in childhood are compatible with developmental science and the classic idea of education as an endeavor that fosters moral character over time from immersion in active social engagement. Moral character cannot emerge from a shortterm intervention, but, as Aristotle advised, must be shaped with mentoring through multiple situations over time.

Of course, moral enhancements that focus on (early) childhood development may be attended by ethical pitfalls, such as the desire to sort children into "good" and "bad," based on caregiving experience. However, regardless of early experience, the nature of the human brain is such that one's moral fate may always be reshaped, at least to some extent (Doidge 2007). Resiliency research in developmental psychology indicates that the brain is plastic beyond early childhood, though some thresholds and systems are established in early life and may be hard if not impossible to change. In any case, early childhood is probably the optimal starting point for moral enhancement.

\section{REFERENCES}

Doidge, N. 2007. The brain that changes itself. New York, NY: Viking Press.

Lupien, S. J., B. S. McEwen, M. R. Gunnar, and C. Heim. 2009. Effects of stress throughout the lifespan on the brain, behaviour and cognition. Nature 10: 434-445.

Narvaez, D. 2006. Integrative ethical education. In Handbook of moral development, ed. M. Killen and J. Smetana, 703-733). Mahwah, NJ: Lawrence Erlbaum Associates. 
Narvaez, D. 2008. Triune ethics: The neurobiological roots of our multiple moralities. New Ideas in Psychology 26: 95-119.

Narvaez, D., J. Panksepp, A. Schore, and T. Gleason (Eds.). 2013. Evolution, early experience and human development: From research to practice and policy. New York, NY: Oxford University Press.

Sobhani, M., and A. Bechara. 2011. A somatic marker perspective of immoral and corrupt behavior. Society for Neuroscience 6(5-6): 640-652.

Nucci, L. P., and D. Narvaez (Eds.). 2008. Handbook of moral and character education. New York, NY: Routledge.

Schore,A.N. 2013. Bowlby's "Environment of Evolutionary Adaptedness:" Recent studies on the interpersonal neurobiology of attachment and emotional development. In Evolution, early experience and human development: From research to practice and policy, ed. D. Narvaez, J. Panksepp, A. N. Schore, and T. Gleason, 31-67. New York, NY: Oxford University Press.

Shook, J. R. 2012. Neuroethics and the possible types of moral enhancement. AJOB Neuroscience 3(4): 3-14.

Tanner, C., and M. Christen. In press. Moral intelligence-A framework for understanding moral competences. In Empirically informed ethics. Morality between facts and norms, ed. M. Christen, J. Fischer, M. Huppenbauer, C. Tanner, and C. van Schaik. Library of Ethics and Applied Philosophy. New York, NY: Springer.

Trevathan,W. R. 2011. Human birth: An evolutionary perspective, 2nd ed. New York, NY: Aldine de Gruyter. 